\title{
The Effect of Perceived Ads Personalization Toward Online Impulse Buying Tendency with Mediating and Moderating Variables, Evidence from Indonesian Millennial E-Commerce Customers
}

\author{
Joshua Christian', Febby Karissa², Boaz Handoyo ${ }^{3}$, \\ Ferdi Antonio 4 \\ Graduate School of Management, \\ Universitas Pelita Harapan, Jakarta, Indonesia \\ joshuacal31@gmail.com
}

\begin{abstract}
E-commerce business grows over time and has changed retail business behavior all over the world. To expand, e-commerce uses ads personalization to study customer needs and track customer behavior. This study aims to analyze the effect of perceived ads personalization towards online impulse buying tendency. The research model hypothesized the effect of perceived ads personalization towards online impulse buying tendency. The mediating variables in this study are perceived novelty, privacy concerns, advertising value, perceived relevance, creepiness, affective reactance, and attitudes towards ads. The study also used a moderating variable of purchasing frequency to distinguish how effective personalized advertising is in groups that are classified as high and the lowfrequency buyer on e-commerce. This study using quantitative research methods with PLS-SEM data analysis. Respondents were taken by purposive sampling on millennial social media users in Jabodetabek. The results showed that perceived advertising personalization had a positive effect on perceived novelty, privacy concern, advertising value, perceived relevance, and creepiness. Furthermore, this study found perceived novelty, advertising value, and perceived relevance have a positive effect on attitudes towards ads. Creepiness indicates a positive effect on affective reactance, while privacy concern and affective reactance have a negative effect on attitudes towards ads. One of the findings is that attitudes towards ads had a positive impact on online impulsive buying tendency. The frequency of purchase is proven to be a moderator that weakens the influence of attitudes towards ads to online impulse buying tendency.

Keywords: perceived ads personalization, perceived novelty, privacy concern, advertising value, perceived relevance, creepiness, affective reactance, attitudes toward ads, online impulse buying tendency, e-commerce
\end{abstract}




$\begin{array}{ll}\text { JEL } & : \text { M3 } \\ \text { DOI } & : 10.24002 / \text { kinerja.v25i1.4357 }\end{array}$

Received : 02/04/2021

Reviewed: 02/11/2021

Final Version: 03/09/2021

\section{INTRODUCTION}

The retail business has been a part of human history since the beginning of human civilization. In 2019, the world's online retail shopping figure has reached $14.1 \%$ of total retail spending, and it is predicted that by 2023 , the world's online retail shopping figure will reach $22 \%$ and will continue to grow in the following years (Copolla, 2020, November 26). In Indonesia alone, data from the Central Statistics Agency (BPS) states, the Indonesian e-commerce industry in the last 10 years has increased by $17 \%$ with a total number of e-commerce businesses reaching 26.2 million units, and in 2019, the total number of transactions ecommerce reached 17.21 trillion rupiahs (BPS, 2019). E-commerce business is predicted to continue to increase in the number of transactions, both in the world and in Indonesia.

In Indonesia itself, e-commerce players with the most users in Indonesia are dominated by e-commerce in the customer-to-customer (C2C) and business-tocustomer (B2B) markets, or a combination of the two. With the intense competition of e-commerce in Indonesia, e-commerce players must be able to find ways to make their platform widely used by internet network users. One of the ways that ecommerce players can do this is by using advertising, especially digital advertising. Internet penetration in Indonesia in 2020 has reached $73.7 \%$ of all Indonesians (APJII, 2020). E-commerce players are competing to use the internet as a promotional medium for their products.

Personalized advertising has become one of the strategies that marketers use in utilizing internet data. Personalization of advertisements utilizing the internet is made possible by cookies technology. The basic function of cookies is to allow the server or site manager to have a memory that will recognize users and their previous activity on the website concerned (Piersen and Heyman 2011). The information collected by cookies can be in the form of user names, to more specific data such as user movements on the internet (history) (Gerdman and Nordqvist, 2017). By implementing ad personalization, companies can get a more specific segment by placing cookies to track customer behavior. The trend of advertising personalization on social media is very relevant to study its effectiveness.

Two of the e-commerce companies in Indonesia that are aggressively implementing ad personalization are Tokopedia and Shopee. These two ecommerce sites with the most users use advertising personalization to promote products sold on the e-commerce platform. Tokopedia and Shopee personalize advertisements on social media platforms such as Instagram and Facebook. Through advertisements on the relevant social media, Tokopedia and Shopee display products that may be liked by social media users based on data obtained by Tokopedia and Shopee from cookie technology. 
Previous research by Dodoo and Wu (2019) wrote that advertising personalization felt by social media users had a significant impact on perceived novelty, advertising value, and perceived relevance than the advertisement in question, but did not find a positive impact of perceived novelty and advertising value on trends impulsive purchases by social media users. Dodoo and Wu's research (2019) has several limitations that can affect the results of the study so that many variables cannot be proven to have a significant impact on other variables, one of which is the absence of a mediating variable that predicts social media user behavior related to trend variables. impulsive buying (online impulse buying tendency). Another limitation is the absence of a variable that measures how the affective reactions of social media users as a form of impulsive action felt by social media users who are exposed to personalized advertising, even though according to the theory of interpersonal behavior (TIB) affection factors also greatly affect human intentions to do something. (Triandis, 1977).

Therefore, this study modifies the research model conducted by Dodoo and Wu (2019) by adding several variables to the research model to get more predictive results. This research aims to extend the previous research with creepiness, affective reactance, attitude, and moderating purchase frequency as the new variables and test the effect of the new variable on the existing model. A model by Barnard (2014) used to accommodate those new variables. A new perspective is presented in this research. Since the model is tested in Indonesia's environment, the research's result able to provide managerial input to decisionmakers in e-commerce operating in Indonesia to consider the use of advertising personalization.

This study also uses the attitudes toward ads variable as a mediating variable that predicts social media user behavior related to the online impulse buying tendency variable. The reasons for using the attitudes toward ads variable include attitudes according to the theory of interpersonal behavior that can predict individual intentions and behavior, and in this study, predicting the intention and behavior of social media users towards impulsive buying tendencies (Triandis, 1977).

\section{LITERATURE REVIEW}

\subsection{Perceived Ad Personalization}

Baek and Morimoto (2012) define advertising personalization as a form of special promotional messages sent by companies to each consumer through paid media based on consumer personal information based on the aggregate probability of relevance of that consumer profile information. Information used for ad personalization can include demographic, psychographic, lifestyle, interests, or behavioral information that can be online or in person. Anderson and Ponnavolu (2002) stated that the benefits of personalized advertising can be felt by both consumers and companies.

Kalyanaraman and Sundar (2006) found a positive effect of personalized content on the website on perceived novelty felt by website visitors, a hypothesis was formulated which predicted that personalization felt by social media users would positively affect the novelty felt by social media users. This study predicts that the personalization that customers perceive from advertising on social media will positively influence their perception of the novelty of advertising. 
H1: Perceived ads personalization positively affects perceived novelty.

In the context of social media advertising, a high level of personalization can trigger a strong feeling that a person's personal information is vulnerable, especially when no explanation is given about how personalization was achieved (Dodoo and Wu, 2019). Previous research from Bleier and Eisenbeiss (2015) showed a significant effect of ads personalization by retailers on the privacy concerns felt by individual consumers. Therefore, a hypothesis is formulated which predicts the personalization that a person feels from social media advertising will positively affect his / her privacy concern.

$\mathrm{H} 2$ : Perceived ads personalization positively affects privacy concerns.

Dodoo and $\mathrm{Wu}$ (2019) found that there is a significant positive effect of perceived ads personalization on advertising value in personalized ads on social media. Strengthened by other research, it has also found that there is a significant effect of advertising personalization on advertising value in advertising on social media (Aydin, 2018). A hypothesis is formulated which predicts that the personalization a person feels from social media advertising will positively affect the values of advertising.

H3: Perceived ads personalization affects advertising value positively.

Kim and Huh (2017) through their research concluded that companies that can understand the needs of their consumers are companies that can find out what they are interested in and provide recommendations in the form of product advertisements that are needed or are attractive to consumers. A hypothesis is formulated which predicts that the personalization that a person feels from social media advertising will positively affect perceived relevance.

H4: Perceived ads personalization positively affects perceived relevance.

Creepiness occurs when the advertisements displayed are too adjusting to someone's privacy and are invasive. Ads that contain too much personal information about someone considered annoying and creepy. Thus, consumers feel that their privacy has been known, followed, observed, and tracked. From previous studies, when marketers create messages that use consumer information that is too personal, it can significantly bring out a sense of creepiness that is felt by consumers (Barnard, 2014; Fachryto and Achyar 2018). A hypothesis is formulated which predicts that the personalization that a person feels from social media advertising will positively affect a sense of creepiness.

H5: Perceived ads personalization positively affects creepiness.

\subsection{Perceived Relevance}

The perceived relevance is expected to positively affect the value of advertising in the context of social media. When customers perceive a high level of relevance in personalized advertising, they can get good advertising value from the ad. This is possible because highly relevant advertisements speak directly to customers' personal needs and interests, providing useful information to guide their behavior. Ads that are considered new will attract the attention of customers, eliminating their annoyance (Dodoo and $\mathrm{Wu}, 2019$ ). Then, a hypothesis is formulated which predicts that the relevance that a person feels of social media advertising will positively affect the values of advertising.

H6: Perceived relevance affects advertising value positively. 


\subsection{Perceived Novelty}

Kim and Yu (2015) found a significant positive effect of creativity and novelty of advertisements on consumer attitudes toward ad. Other research from Kalyanaraman and Sundar (2006) shows that there is a significant positive impact of a personalized website with the attitude that consumers feel about the website. From the above reasons, a hypothesis was formulated which predicts that a person's perceived novelty from social media advertisements will positively affect attitudes toward ad.

\section{H7: Perceived novelty affects attitudes toward ads}

\subsection{Privacy Concern}

Previous research from Phelps, D'souza, and Nowak (2001) found that privacy concern is negatively related to the effects of advertising. Privacy concerns lead people to a negative attitude towards advertising when faced with requests for personal data. Then Baek and Morimoto (2012) explain that privacy concerns can increase skepticism and tend to avoid advertisements. Previous research from Limpf and Voorvelt (2015) also found negative significant effect of privacy concern on personalized advertising affect user's attitude toward the advertisement, then the proposed hypothesis:

H8: Privacy concern negatively affects attitudes toward ads.

\subsection{Advertising Value}

Ducoffe (1996) stated that informativeness, irritation, and entertainment are key factors in assessing the value of advertising. Another important result is that there is a positive and significant relationship between advertising value and attitudes toward ads. Tsang, Ho, and Liang (2004) also explained that informativeness in the advertising value of an advertisement has a positive relationship with consumer attitudes towards advertising. Another study from Mahatmavidya and Yasa (2020) found positive significant effect of social media's ads advertising value toward users' attitudes toward the advertisement. Then the advertising value hypothesis for attitudes toward ads is:

H9: Advertising value affects attitudes toward ads positively.

\subsection{Perceived Relevance}

Ads that have relevance to consumer needs can create positive attitudes (Kim and Han, 2014). Then it was also found that consumers who are exposed to relevant and meaningful content will give a more positive attitude to the advertisements given. Study from Kim and Huh (2017) found that the perceived ad relevance of personalized internet advertisement affects the internet users' attitudes toward the advertisement positively. Then the hypothesis is:

H10: Perceived relevance positively affects attitudes toward ads.

\subsection{Affective Reactance}

Barnard (2014) writes that behavioral tailoring or personalized ads can increase feelings of creepy (being watched, tracked, and targeted by marketers) so that consumers feel threatened, and reactance is formed, which results in negative attitudes towards advertisements and attitude toward ads displayed by advertiser companies. Then, affective reactance theory states that when persuasive requests threaten a person's freedom, people are motivated to reject or 
reject messages and tend to perceive a message to be negative (Brehm and Brehm, 1981). Then the hypothesis that is formed is:

$\mathrm{H} 11$ : Creepiness affects the affective reactance positively.

H12: Affective reactance negatively affects attitudes toward ads.

\subsection{Online Impulse Buying Tendencies}

Impulse buying according to Verplanken and Herabadi (2011) is a situation where consumers can buy products or services to relieve a depressed mood, showing identity, or just having fun apart from meeting certain needs. Verhagen and Dolen (2011) also state that the two core elements that characterize impulse buying are unplanned processes and do not have cognitive considerations. The process is triggered by product discovery while exploring the store and does not lead to the cognitive formation, but attitude or intention. Second, emotions dominate the impulse buying process. Thus, impulse buying can be predicted as being influenced by emotional factors or attitudes, so the hypothesis made is:

H13: Attitudes toward ads positively affect online impulse buying tendencies.

Shim (2001) states that the experience with online shopping directly affects the attitude shown by consumers. Thus, online purchase intentions in consumers can be influenced directly and indirectly according to consumers' previous online shopping experiences. Liang and Huang (1998) found that previous consumer experiences had a moderate effect in predicting their acceptance of subsequent online shopping. Besides, Castaneda, Munozleiva, and Luque (2007) have found high acceptance rates in the level of online shopping and website experiences that can moderate the impact of perceived usefulness on future user intentions. Then the shopping frequency is chosen as the moderating variable.

$\mathrm{H} 14$ : The frequency of shopping moderates the relationship of attitudes toward ads with online impulse buying tendencies.

\section{RESEARCH METHOD}

The method used in this study is an explanatory survey with a quantitative approach, where the data collection of numbers is obtained through structured questions, which will explain and analyze the effect of perceived ads personalization and attitudes toward ads on online impulse buying tendency with purchasing frequency (Now and Bougie, 2016) developed through indicators that can be measured using applied statistics. Applied statistics are used to test research hypotheses and an understanding of phenomena and theories based on research results that will contribute to generating more knowledge.

\subsection{Data Acquisition}

Two data will be used in this research, namely primary data and secondary data. Primary data is data that is collected directly through a questionnaire. The questionnaire in this study used Google Form, which was distributed using email, social media (Facebook), and chat applications (Line and Whatsapp) from October to November 2020. Meanwhile, secondary data is data taken from intermediary media such as journals, books, or reports that support performance. 


\subsection{Data Analysis Method}

In the quantitative data analysis method, the multivariate analysis method is used which can simultaneously analyze many variables that influence each other at the same time (Hair, Hult, Ringle, and Sarstedt, 2014). The multivariate analysis method can be run and calculated through SEM (structural equation modeling) modeling which can also test if there are mediating and moderating variables simultaneously. SEM can test the quality of the model proposed during the empirical test (R2 and Q2 values) (Hair, Hult, Ringle, and Sarstedt, 2016) and determine the validity and reliability of a model.

\subsection{Variables}

This study consists of 10 variables regarding perceived ads personalization consisting of attitudes toward ads, perceived novelty, personal relevance, privacy concern, advertising value, creepiness, and affective reactance with purchasing frequency as a moderator to the online impulse buying tendency. The variables in this study were divided into dependent variables, independent variables, and moderating variables. Dependent variables become the most essential to understand and explain its variability, or to predict it. The dependent variable is directly influenced by the independent variable. Moderating variables are variables that have a strong contingency effect on the relationship between the dependent variable and the independent variable (Sekaran and Bougie, 2016).

In this study, the independent variable is perceived ads personalization, coupled with a mediating variable consisting of attitudes toward ads, perceived novelty, personal relevance, privacy concern, advertising value, creepiness, and affective reactance. The moderating variable in this study was purchasing frequency, while the dependent variable in this study was the online impulse buying tendency.

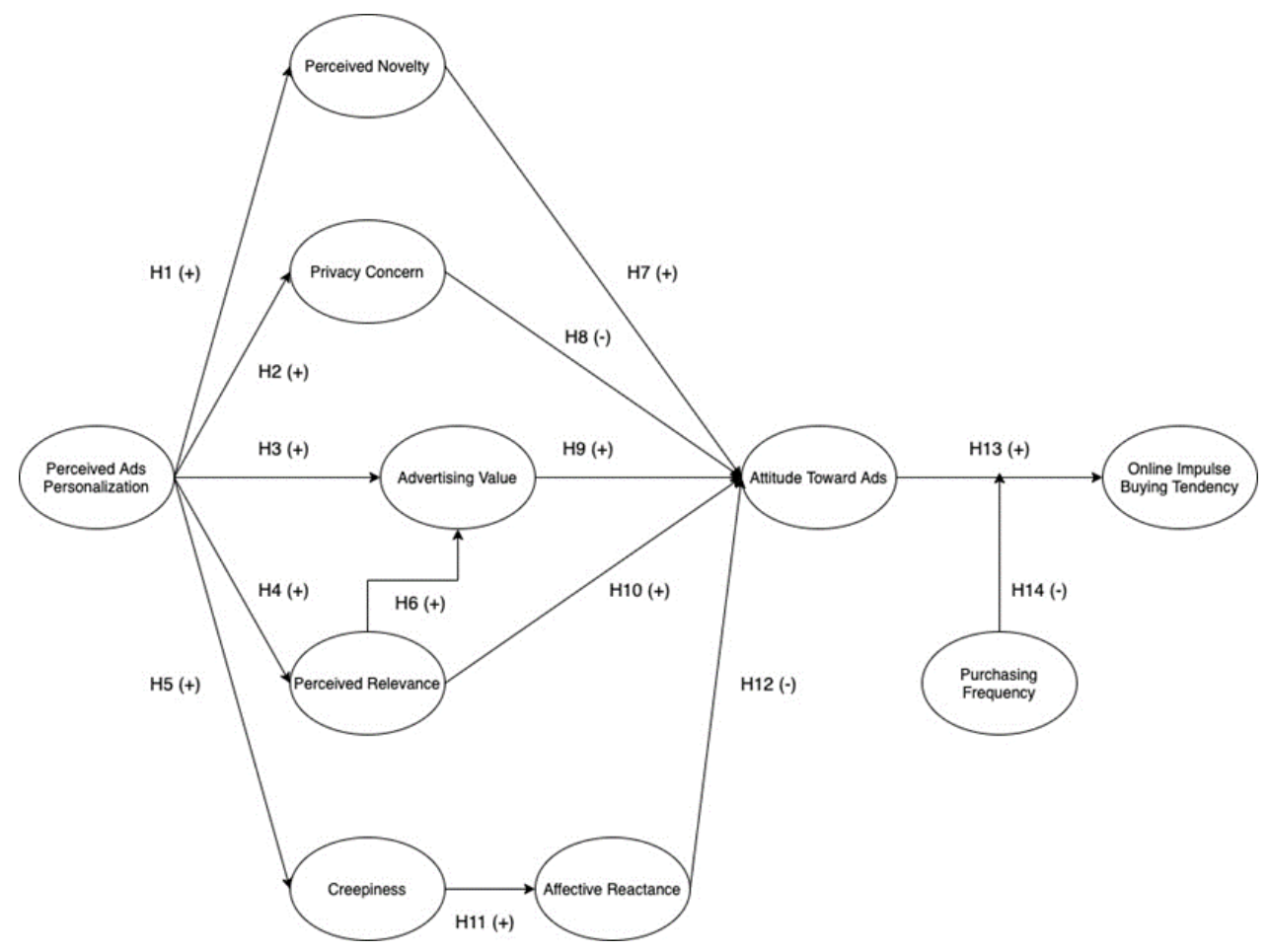

Figure 1. Research Model (Perceived Ads Personalization towards Online Impulse Buying Tendency 


\section{DATA ANALYSIS AND DISCUSSION}

\subsection{Modeling}

Based on the hypothesis discussed in section 2, the research model (Figure 1) was formed with online impulse buying tendency as the dependent variable, perceived ads personalization as an independent variable, 6 mediating variables, namely perceived novelty, privacy concern, advertising value, perceived relevance, creepiness, affective reactance, attitude toward ads, and also purchasing frequency as a moderating variable.

In addition to the modification of the previous research model from Dodoo and Wu (2019) and Barndard (2014), this study includes the frequency of shopping that is added as a moderating variable based on Triandis' theory of interpersonal behavior (1977), it is stated that the frequency of someone doing something continuously can trigger habits that can also influence a person's intentions and generate specific responses. Based on the number of variables used, it can be said that this study applies a complex model, so a multivariate analysis method is needed, which means that many variables can affect several other variables at the same time (Hair, Hult, Ringle, abd Sarstedt, 2014). Also, to obtain predictive results and to explain the relationship of each construct well, the analysis was used with the PLS-SEM software, namely SmartPLS @3.3.2.

\subsubsection{Measurement Model or Outer Model}

The first step of the measurement model being carried out is checking the loadings indicator. The second step is to evaluate the internal consistency reliability which consists of Cronbach's alpha and composite reliability. The higher the value, the higher the level of reliability. The third step is to use the average variance extracted (AVE) to determine the convergent validity at the construct level as the grand mean value of the squared loadings of the indicators associated with the construct (Hair et al., 2014). The fourth step is to look at discriminant validity introduced by Henseler, Ringle, and Sarstedt (2015), namely the heterotrait-monotrait ratio of correlations (HTMT) as a measure of similarity between latent variables.

\subsubsection{Structural Model or Inner Model}

The next step is to evaluate the structural model based on the value of variance inflation factor (VIF), R2 test, Q2 test, hypothesis test, specific indirect effect test, and finally the importance-performance map analysis (IPMA) test. Variance inflation factor (VIF) is used to measure the extent to which standard error increases due to collinearity / the opposite of tolerance (Hair et al., 2019). Next is to evaluate the structural model using the coefficient of determination (R2) which produces the amount of variance in the construct and can measure the accuracy of the model's prediction (Chin, 2009). In this study, it is also necessary to examine the predictive relevance of the model which can be seen on the Q2 indicator (Hair et al., 2014). Hypothesis testing in this study was carried out by looking at the T-Statistics value and the P-Values value.

The next step is to assess the relevance of the path coefficient using the bootstrap function so that the construct of the indirect effect on a particular target or intervening can be evaluated. (Nitzl, Roldan, and Cepeda, 2016). The indirect effect has relevance in assessing the mediating effect, which can measure a 
mediation test of a model. The specific indirect effect describes the overall indirect effect between a variable on other variables.

Importance-performance matrix analysis (IPMA) which produces latent variable scores as the main characteristic of the PLS-SEM method is useful for extending the findings of basic PLS-SEM results using latent variable scores from the path model relationships and additional dimensions created for analysis purposes (Gronholdt et al., 2010). The IPMA compares the total effect of the structural model (importance) and the mean scores of latent variables (performance) to find significant areas for future improvement. More specifically, the results can be used to identify determinants with relatively high importance and relatively low performance (Hair et al., 2014).

\subsection{Result}

\subsubsection{Reliability and Validity}

The outer model test is conducted to test the validity and reliability of a research model. In this research, test the outer model using the PLS Algorithm. According to Hair et al., (2019), an indicator is said to be reliable if the outer loading value is more than 0.708 because it can indicate that the construct explains more than $50 \%$ of the variance of the indicator. The outer loading (see Table 1) ranged from 0.717 to 0.935 , which highly significant.

Table 1. Test Results of Outer Loading, Cronbach Alpha, Composite Reliability (CR), and Average Variance Extracted (AVE)

\begin{tabular}{|c|c|c|c|c|c|c|}
\hline Variables & Indicator & Outer Loading & Cronbach's Alpha & Composite Reliability & $\begin{array}{l}\text { Average Variance } \\
\text { Extracted (AVE) }\end{array}$ & Result \\
\hline \multirow{6}{*}{$\begin{array}{l}\text { Perceived Ads } \\
\text { Personalization }\end{array}$} & PAP1 & 0.848 & 0.898 & 0.922 & 0.663 & Reliable \\
\hline & PAP2 & 0.785 & & & & Reliable \\
\hline & PAP3 & 0.828 & & & & Reliable \\
\hline & PAP4 & 0.739 & & & & Reliable \\
\hline & PAP5 & 0.836 & & & & Reliable \\
\hline & PAP6 & 0.843 & & & & Reliable \\
\hline \multirow{2}{*}{$\begin{array}{l}\text { Perceived } \\
\text { Novelty }\end{array}$} & PN1 & 0.829 & 0.72 & 0.873 & 0.775 & Reliable \\
\hline & PN2 & 0.928 & & & & Reliable \\
\hline \multirow{5}{*}{ Privacy Concern } & $\mathrm{PC} 1$ & 0.737 & 0.894 & 0.922 & 0.703 & Reliable \\
\hline & PC2 & 0.86 & & & & Reliable \\
\hline & PC3 & 0.874 & & & & Reliable \\
\hline & PC4 & 0.87 & & & & Reliable \\
\hline & PC5 & 0.844 & & & & Reliable \\
\hline \multirow{2}{*}{$\begin{array}{l}\text { Perceived } \\
\text { Relevance }\end{array}$} & PR1 & 0.932 & 0.853 & 0.931 & 0.872 & Reliable \\
\hline & PR2 & 0.935 & & & & Reliable \\
\hline \multirow{3}{*}{ Advertising Value } & AV1 & 0.806 & 0.796 & 0.879 & 0.707 & Reliable \\
\hline & AV2 & 0.851 & & & & Reliable \\
\hline & AV3 & 0.865 & & & & Reliable \\
\hline \multirow{4}{*}{ Creepiness } & CR1 & 0.881 & 0.905 & 0.934 & 0.779 & Reliable \\
\hline & CR2 & 0.889 & & & & Reliable \\
\hline & CR3 & 0.89 & & & & Reliable \\
\hline & CR4 & 0.87 & & & & Reliable \\
\hline \multirow{4}{*}{$\begin{array}{l}\text { Affective } \\
\text { Reactance }\end{array}$} & AR1 & 0.827 & 0.887 & 0.922 & 0.747 & Reliable \\
\hline & AR2 & 0.866 & & & & Reliable \\
\hline & AR3 & 0.873 & & & & Reliable \\
\hline & AR4 & 0.89 & & & & Reliable \\
\hline \multirow{4}{*}{$\begin{array}{c}\text { Attitudes Toward } \\
\text { Ads }\end{array}$} & ATAl & 0.827 & 0.857 & 0.903 & 0.7 & Reliable \\
\hline & ATA2 & 0.846 & & & & Reliable \\
\hline & ATA3 & 0.837 & & & & Reliable \\
\hline & ATA4 & 0.837 & & & & Reliable \\
\hline \multirow{7}{*}{$\begin{array}{c}\text { Online Impulse } \\
\text { Buying Tendency }\end{array}$} & IBT1 & 0.832 & 0.902 & 0.923 & 0.632 & Reliable \\
\hline & IBT2 & 0.832 & & & & Reliable \\
\hline & IBT3 & 0.854 & & & & Reliable \\
\hline & IBT4 & 0.789 & & & & Reliable \\
\hline & IBT5 & 0.787 & & & & Reliable \\
\hline & IBT6 & 0.717 & & & & Reliable \\
\hline & IBT7 & 0.745 & & & & Reliable \\
\hline
\end{tabular}


The construct reliability test is measured by two criteria, namely composite reliability and Cronbach alpha. A construct is said to be reliable if the Cronbach alpha value is greater than 0.70 . Cronbach's alpha ranged from 0.72 to 0.905 , exceeding the minimum limit of 0.70 . The composite reliability $(C R)$ value between 0.60 to 0.70 was assessed by Hair as acceptable in exploratory research. In this research, $C R$ values ranged from 0.873 to 0.905 . CR value ranged between 0.70 and 0.90 was considered as satisfactory good (Hair et al., 2019). Average Variance Extracted (AVE) measurement to measure the convergent validity of each construct. The acceptable AVE value is 0.50 or higher and the result (see Table 1) ranged from 0.632 to 0.872 , which means that each variable is valid to measure the convergent validity of each construct.

To sum up, the result shows that the outer model. Cronbach alpha, composite reliability, and average variance extracted from each variable used in this study are acceptable (see Table 1).

The next step in the outer model test is to assess discriminant validity to assess the extent to which the construct empirically differs from other constructs in the structural model. The discriminant validity test was carried out by using the cross-loading factor value by comparing the AVE roots with the correlation between latent variables or constructs. Henseler et al., (2015) proposed to test the discriminant validity using the Heterotrait - Monotrait Ratio (HTMT). The HTMT value less than 0.9 indicates that the discriminant validity has been fulfilled. HTMT value for each variable is below 0.9 (see Table 2 ), which means that the indicators are right for testing each construct.

Table 2. Result of Discriminant Validity Test with Heterotrait - Monotrait Ratio of Correlation Method

\begin{tabular}{|c|c|c|c|c|c|c|c|c|c|c|c|}
\hline & 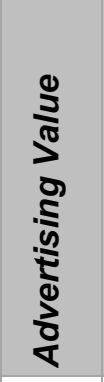 & 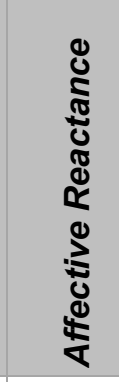 & 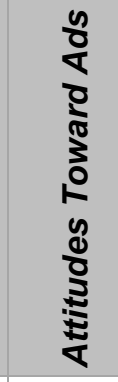 & 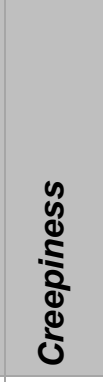 & $\begin{array}{l}\text { वे } \\
\text { बे } \\
\text { वे } \\
\text { एँ }\end{array}$ & 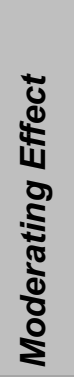 & 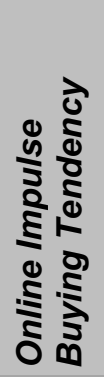 & 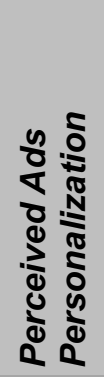 & 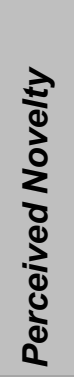 & 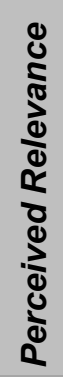 & 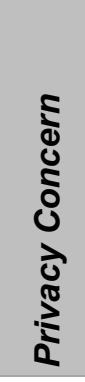 \\
\hline \multicolumn{12}{|l|}{$\begin{array}{l}\text { Advertising } \\
\text { Value }\end{array}$} \\
\hline $\begin{array}{l}\text { Affective } \\
\text { Reactance }\end{array}$ & 0.151 & & & & & & & & & & \\
\hline $\begin{array}{l}\text { Attitudes } \\
\text { Toward Ads }\end{array}$ & 0.763 & 0.175 & & & & & & & & & \\
\hline Creepiness & 0.152 & 0.449 & 0.116 & & & & & & & & \\
\hline Frequency & 0.382 & 0.214 & 0.291 & 0.194 & & & & & & & \\
\hline Moderating & 0.170 & 0.039 & 0.237 & 0.106 & 0.319 & & & & & & \\
\hline
\end{tabular}




\begin{tabular}{|c|c|c|c|c|c|c|c|c|c|c|c|}
\hline & $\begin{array}{l}\frac{1}{3} \\
\frac{10}{5} \\
0 \\
\frac{1}{4} \\
\frac{1}{0} \\
\frac{0}{0}\end{array}$ & 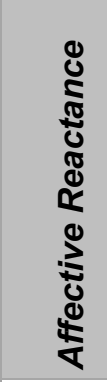 & 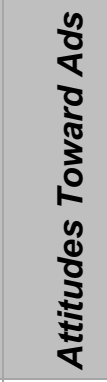 & 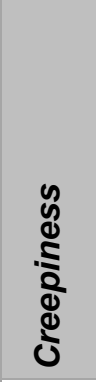 & $\begin{array}{l}\text { லे } \\
\frac{1}{0} \\
\frac{0}{0} \\
\frac{1}{4}\end{array}$ & 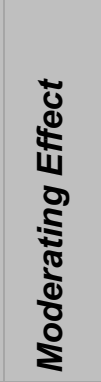 & 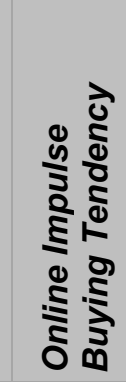 & 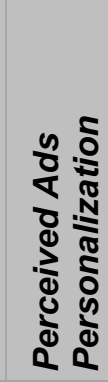 & 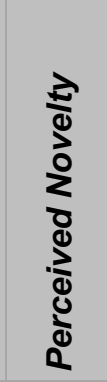 & 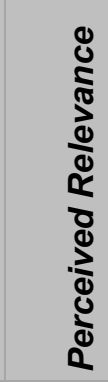 & 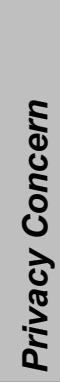 \\
\hline \multicolumn{12}{|l|}{ Effect } \\
\hline $\begin{array}{l}\text { Online Impulse } \\
\text { Buying } \\
\text { Tendency }\end{array}$ & 0.556 & 0.279 & 0.462 & 0.345 & 0.782 & 0.185 & & & & & \\
\hline $\begin{array}{l}\text { Perceived Ads } \\
\text { Personalization }\end{array}$ & 0.523 & 0.088 & 0.592 & 0.461 & 0.254 & 0.053 & 0.465 & & & & \\
\hline $\begin{array}{l}\text { Perceived } \\
\text { Novelty }\end{array}$ & 0.627 & 0.178 & 0.686 & 0.405 & 0.322 & 0.058 & 0.564 & 0.615 & & & \\
\hline $\begin{array}{l}\text { Perceived } \\
\text { Relevance }\end{array}$ & 0.539 & 0.048 & 0.537 & 0.356 & 0.239 & 0.045 & 0.427 & 0.721 & 0.578 & & \\
\hline Privacy Concern & 0.118 & 0.523 & 0.070 & 0.800 & 0.100 & 0.115 & 0.305 & 0.365 & 0.408 & 0.207 & \\
\hline
\end{tabular}

\subsection{Hypothesis Testing}

Empirical data analysis was carried out according to the PLS-SEM method. From the results of hypothesis testing (See Table 3) on social media users Facebook and Instagram on personalized Shopee and Tokopedia ads, the following conclusions can be drawn:

Table 3. Hypothesis Testing Results

\begin{tabular}{llllll}
\hline Hyphothesis & \multicolumn{1}{c}{ Path } & $\begin{array}{c}\text { Standardized } \\
\text { Coefficient }\end{array}$ & $\begin{array}{c}\text { T- } \\
\text { Value }\end{array}$ & Significance & Result \\
\hline H1 & $\begin{array}{l}\text { Perceived Ads } \\
\text { Personalization -> Perceived } \\
\text { Novelty }\end{array}$ & 0.512 & 10.493 & Significant & $\begin{array}{l}\text { Hypothesis } \\
\text { Supported }\end{array}$ \\
& $\begin{array}{l}\text { Perceived Ads } \\
\text { Personalization -> Privacy } \\
\text { Concern }\end{array}$ & 0.334 & 6.243 & Significant & $\begin{array}{l}\text { Hypothesis } \\
\text { Supported }\end{array}$ \\
& $\begin{array}{l}\text { Perceived Ads } \\
\text { Personalization -> Advertising }\end{array}$ & 0.265 & 3.825 & Significant & $\begin{array}{l}\text { Hypothesis } \\
\text { Supported }\end{array}$ \\
Value & $\begin{array}{l}\text { Perceived Ads } \\
\text { Personalization -> Perceived } \\
\text { Relevance }\end{array}$ & 0.633 & 15.330 Significant & $\begin{array}{l}\text { Hypothesis } \\
\text { Supported }\end{array}$ \\
& $\begin{array}{l}\text { Perceived Ads } \\
\text { Personalization -> } \\
\text { Creepiness_ }\end{array}$ & 0.421 & 8.900 & Significant & $\begin{array}{l}\text { Hypothesis } \\
\text { Supported }\end{array}$ \\
H5 & & & & \\
\hline
\end{tabular}




\begin{tabular}{|c|c|c|c|c|c|}
\hline Hyphothesis & Path & $\begin{array}{l}\text { Standardized } \\
\text { Coefficient }\end{array}$ & $\begin{array}{c}\text { T- } \\
\text { Value }\end{array}$ & Significance & Result \\
\hline $\mathrm{H} 6$ & $\begin{array}{l}\text { Perceived Relevance -> } \\
\text { Advertising Value }\end{array}$ & 0.293 & 4.069 & Significant & $\begin{array}{l}\text { Hypothesis } \\
\text { Supported }\end{array}$ \\
\hline $\mathrm{H} 7$ & $\begin{array}{l}\text { Perceived Novelty -> } \\
\text { Attitudes Toward Ads }\end{array}$ & 0.342 & 6.090 & Significant & $\begin{array}{l}\text { Hypothesis } \\
\text { Supported }\end{array}$ \\
\hline $\mathrm{H} 8$ & $\begin{array}{l}\text { Privacy Concern -> Attitudes } \\
\text { Toward Ads }\end{array}$ & -0.109 & 2.508 & Significant & $\begin{array}{l}\text { Hypothesis } \\
\text { Supported }\end{array}$ \\
\hline H9 & $\begin{array}{l}\text { Advertising Value -> Attitudes } \\
\text { Toward Ads }\end{array}$ & 0.415 & 7.316 & Significant & $\begin{array}{l}\text { Hypothesis } \\
\text { Supported }\end{array}$ \\
\hline $\mathrm{H} 10$ & $\begin{array}{l}\text { Perceived Relevance -> } \\
\text { Attitudes Toward Ads }\end{array}$ & 0.130 & 2.236 & Significant & $\begin{array}{l}\text { Hypothesis } \\
\text { Supported }\end{array}$ \\
\hline $\mathrm{H} 11$ & $\begin{array}{l}\text { Creepiness__> Affective } \\
\text { Reactance }\end{array}$ & 0.411 & 11.343 & Significant & $\begin{array}{l}\text { Hypothesis } \\
\text { Supported }\end{array}$ \\
\hline $\mathrm{H} 12$ & $\begin{array}{l}\text { Affective Reactance -> } \\
\text { Attitudes Toward Ads }\end{array}$ & -0.124 & 2.330 & Significant & $\begin{array}{l}\text { Hypothesis } \\
\text { Supported }\end{array}$ \\
\hline $\mathrm{H} 13$ & $\begin{array}{l}\text { Attitudes Toward Ads -> } \\
\text { Online Impulse Buying } \\
\text { Tendency }\end{array}$ & 0.232 & 6.789 & Significant & $\begin{array}{l}\text { Hypothesis } \\
\text { Supported }\end{array}$ \\
\hline $\mathrm{H} 14$ & $\begin{array}{l}\text { Attitudes Toward Ads } \\
\text { *Purchase frequency -> } \\
\text { Online Impulse Buying } \\
\text { Tendency }\end{array}$ & -0.085 & 3.402 & Significant & $\begin{array}{l}\text { Hypothesis } \\
\text { Supported }\end{array}$ \\
\hline
\end{tabular}

1. Perceived ads personalization is proven to have a significant positive effect on perceived novelty, the T-statistic> 1.645, and the path coefficient is positive, the hypothesis is supported. If the perceived advertising personalization increases, the perceived novelty will also increase.

2. Perceived ads personalization is proven to have a significant positive effect on privacy concern, the T-statistic $>1.645$, and the path coefficient is positive, the hypothesis is supported. If the personalization of the advertisements is increased, the privacy concern that is felt will also increase.

3. Perceived ads personalization is proven to have a significant positive effect on advertising value, the T-statistic> 1.645, and the path coefficient is positive, then the hypothesis is supported. If the perceived advertising personalization increases, the perceived advertising value will also increase.

4. Perceived ads personalization is proven to have a significant positive effect on perceived relevance, the T-statistic> 1.645, and the path coefficient is positive, then the hypothesis is supported. When the perceived ad personalization increases, the perceived relevancewill

5. Perceived ads personalization is proven to have a significant positive effect on creepiness, the T-statistic > 1.645, and the path coefficient is positive, then the hypothesis is supported. If the perceived personalization of the advertisement increases, the creepiness that is felt will also increase.

6. Perceived relevance is proven to have a significant positive effect on advertising value, the T-statistic $>1.645$, and the path coefficient is positive, then the hypothesis is supported. If the perceived relevance of personalized advertising increases, the perceived value of advertising will also increase. 
7. Perceived novelty is shown to have a significant positive effect on attitudes toward ads, the T-statistic $>1.645$, and the path coefficient is positive, then the hypothesis is supported. If the perceived novelty towards personalized advertising increases, the attitudes toward ads will also increase.

8. Privacy concern has been shown to have a significant negative effect on attitudes toward ads, the T-statistic> 1.645, and the path coefficient is negative, then the hypothesis is supported. When the perceived privacy concern for personalized advertising increases, the attitudes toward ads decrease.

9. Advertising value is proven to have a significant positive effect on attitudes toward ads, the T-statistic $>1.645$, and the path coefficient is positive, then the hypothesis is supported. If the perceived value of advertising towards personalized advertising increases, the attitudes toward ads will also increase.

10. Perceived relevance is shown to have a significant positive effect on attitudes toward ads, the T-statistic $>1.645$, and the path coefficient is positive, the hypothesis is supported. If the perceived relevance of personalized advertising increases, the attitudes toward ads will also increase.

11. Creepiness is proven to have a significant positive effect on affective reactance, the T-statistic $>1.645$, and the path coefficient is positive, then the hypothesis is supported. If the perceived creepiness of personalized advertising increases, the affective reaction will also increase.

12. Affective reactance is shown to have a significant negative effect on attitudes toward ads, the T-statistic> 1.645, and the path coefficient is negative, then the hypothesis is supported. When the perceived affective reaction to personalized advertising increases, the attitudes toward ads decrease.

13. Attitudes toward ads have a significant positive effect on online impulse buying tendency, the T-statistic> 1.645, and the path coefficient is positive, then the hypothesis is supported. If the attitudes toward ads increase, the online impulse buying tendency also increases.

14. Purchasing frequency moderate's attitudes toward ads with online impulse buying tendency negatively, the T-statistic $>1.645$, and the path coefficient is positive, then the hypothesis is supported. Purchasing frequency weakens the relationship between attitudes toward ads and online impulse buying tendency. 


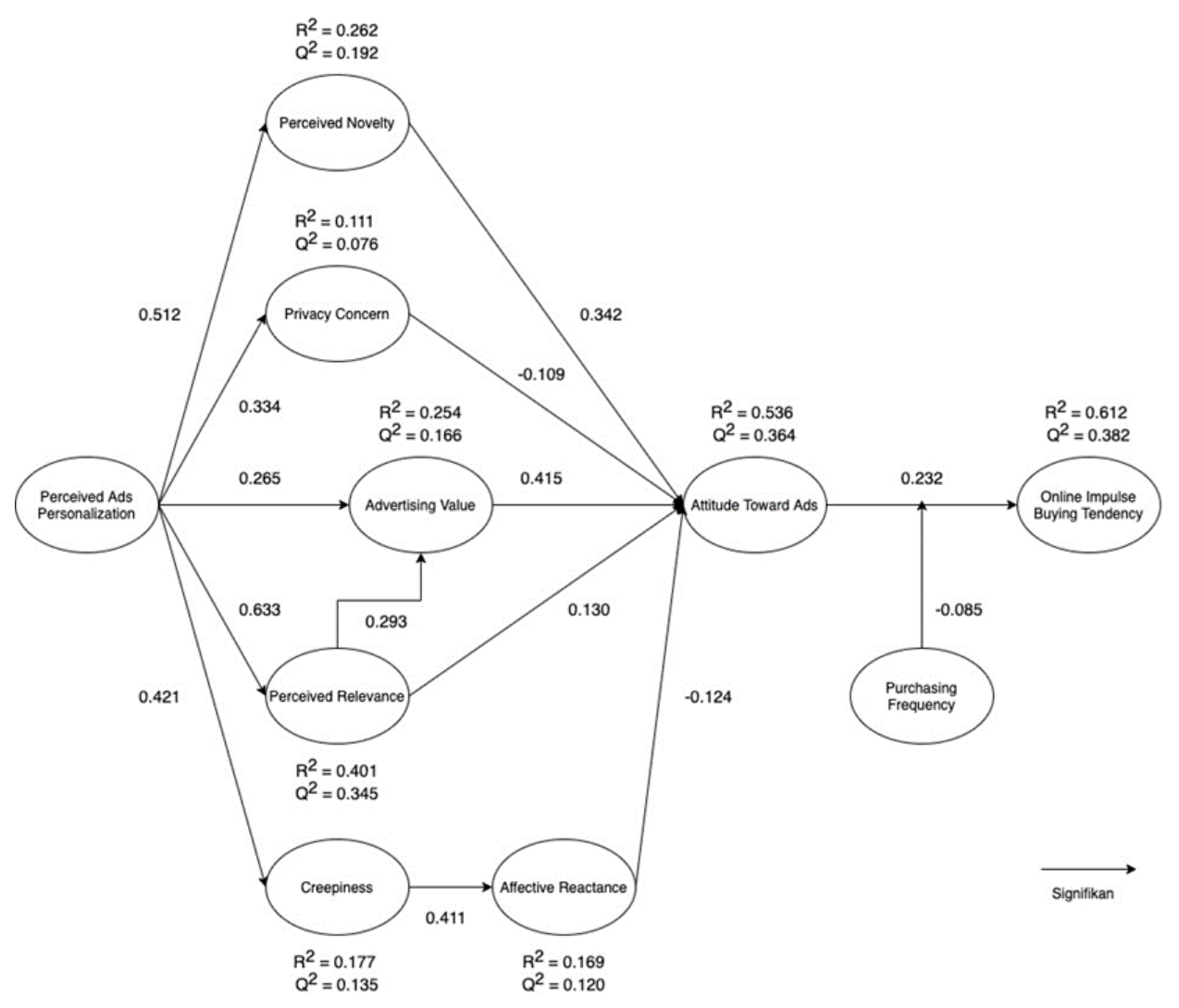

Figure 2. Model's Result

The proposed modification model has moderate predictive accuracy and large predictive relevance which is obtained from the R-square and Q-square predict data.

\subsection{Discussion}

The purpose of this study is to test the proposed modification model based on previous research from Dodoo and Wu (2019) and Barnard (2014). This model is modified with variables attitudes toward ads, creepiness, and affective reactance. The new criterion in this study is that in testing perceived personalized ads, it is necessary to pay attention to purchasing frequency to get a more effective and stronger managerial implication. From the data analysis of PLS-SEM, an empirical model can be described as below:

The strongest path of this model is perceived ads personalization -> perceived novelty $->$ attitudes toward ads $->$ online impulse buying tendency. This shows that personalized advertising is most effective in changing the tendency of online purchases by consumers if it is through the novelty that consumers feel, then through the positive attitude shown by consumers towards advertising. The use of personalization ads can increase margins and revenue if done effectively and efficiently because it can reduce costs like the old procedure in advertising (out-ofhome advertising).

Based on the results of this study, it was found that of the 14 hypotheses, all of them showed significant results that supported the hypothesis. Attitudes toward ads can be predicted to be the strongest by perceived novelty so that to produce a positive attitude towards ads, content creators must pay attention to the novelty presented in each ad content. Then, perceived personalized ads have the greatest 
positive influence on perceived relevance, thus perceived relevance can be used as a variable to evaluate the extent of the effect of perceived personalization ads. Besides, attitudes toward ads can predict a moderate online impulse buying tendency. This relationship is also weakened by purchasing frequency as a moderating variable. If the purchasing frequency is done more frequently, the online impulse buying tendency will get weaker.

\section{CONCLUSION}

One of the objectives of this study is to provide managerial implications for the Indonesian e-commerce managerial team who use the personalized ads advertising strategy. The managerial implications that can be applied by Indonesian e-commerce can focus their marketing efforts on groups of women with demographic profiles as mentioned above. The above profile also shows that women in the 21-26 age group have their purchasing power without depending on other people to shop on e-commerce.

This research can also suggest that management continues to use personalized ads advertising strategies to increase sales. The use of social media for Facebook and Instagram has also been a good choice for management because this study found the use of both social media for personalized advertising has been effective in changing consumer behavior to make impulsive purchases. The moderating variable that this study found also shows that advertising personalization is more effective for groups of social media users who spend less frequently on e-commerce, this finding can be an input for management to focus more personalized advertising marketing efforts on consumer groups. social media users who rarely shop online.

However, managers must also pay attention to how ad personalization can create bad emotions among social media users, especially related to privacy issues that make social media users feel that their data is being taken by social media platforms and advertisers. Another negative emotion that arises from the use of personalized advertising is the creepy feeling that is felt by social media users. Social media users feel being watched, followed, and tracked by corporate advertisers which can result in a sense of annoyance.

\section{REFERENCES}

APJII., 2020. Laporan Survey: Penetrasi \& Profil Perilaku Pengguna Internet Indonesia. Jakarta: APJII.

Aydin, G., 2016. Role of Personalization in Shaping Attitudes Towards Social Media Ads. International Journal of E-Business Research. 14(3), 54-76. https://doi.org/10.4018/IJEBR.2018070104

Baek, T.,H. and Morimoto, M., 2012. Stay away from me. Journal of advertising, 41(1), 59-76.

Barnard, L., 2014. The Cost of Creepiness: How Online Behavioral Advertising Affects Consumer Purchase Intention. Ph.D. Dissertation. The University of North Carolina at Chapel Hill. https://doi.org/10.17615/7fmw-1r29. 
Bleier, A. and Eisenbeiss, M., 2015. The Importance of Trust for Personalized Online Advertising. Journal of Retailing, 91(3), 390-409.

https://doi.org/10.1016/j.jretai.2015.04.001.

BPS., 2019. Statistik E-Commerce 2019.

Brehm, S. S., and Brehm, J. W., 1981. Psychological Reactance: A Theory of Freedom and Control. New York: Academic Press.

Castaneda, J., Munozleiva, F. and Luque, T., 2007. Web acceptance model (WAM): Moderating effects of user experience. Information \& Management, 44 (4), 384-396. https://doi.org/10.1016/j.im.2007.02.003.

Chin, W.W., 2009. How to Write Up and Report PLS Analyses. Handbook of Partial Least Squares. pp. 650-690. DOI: 10.1007/978-3-540-32827-8 29.

Dodoo, N.A. and Wu, L., 2019. Exploring The Anteceding Impact Of Personalised Social Media Advertising On Online Impulse Buying Tendency. International Journal Internet Marketing and Advertising, 13(1), 73-95. DOI:

10.1504/IJIMA.2019.10019167.

Ducoffe, R. H., 1996. Advertising Value and Advertising on the Web. Journal of Advertising Research, 36(5), 21-36.

Fachryto, T., and Achyar A., 2018. Effect of Online Behavioral Advertising Implementation on Attitude toward Ad and Purchase Intention in Indonesian EMarketplace. Sriwijaya International Journal of Dynamic Economics and Business, 2(2). pp. 123-138. https://doi.org/10.29259/sijdeb.v2i2.123-138.

Gerdman, T. and Nordqvist F., 2017. An Exploratory study on Perceptions of Personalised Display Ads Online. Jönköping: Jönköping University.

Gronholdt, L., Martensen, A., and Kristensen, K., (2010). The relationship between customer satisfaction and loyalty: Cross-industry differences. Total Quality Management, 11(4-6), 509-514. http://dx.doi.org/10.1080/09544120050007823.

Hair, J., F., Hult, G., T., M., Ringle, C., M., and Sarstedt, M., 2014. A Primer on Partial Least Squares Structural Equation Modeling (PLS-SEM). European Business Review,26(2), 106-121. https://doi.org/10.1108/EBR-10-2013-0128.

Hair Jr, J. F., Hult, G. T. M., Ringle, C., and Sarstedt, M., 2016. A primer on partial least squares structural equation modeling (PLS-SEM). Sage publications.

Hair, J.F., Risher, J.J., Sarstedt, M. and Ringle, C.M., (2019).When to use and how to report the results of PLS-SEM. European Business Review, 31(1), 2-24. https://doi.org/10.1108/EBR-11-2018-0203.

Henseler, J., Ringle, C. M., and Sarstedt, M., 2015. A New Criterion For Assessing Discriminant Validity In Variance-Based Structural Equation Modeling. Journal of the Academy of Marketing Science, 43, 115-135. DOI: 10.1007/s11747-014-04038.

Kalyanaraman, S., and Sundar, S. S., 2006. The Psychological Appeal of Personalized Content in Web Portals: Does Customization Affect Attitudes and Behavior? Journal of Communication, 56(1), 110-132. https://doi.org/10.1111/j.1460-2466.2006.00006.x. 
Kim, Y. J., and Han, J. Y. 2014., Why Smartphone Advertising Attracts Customers: A Model Of Web Advertising, Flow, And Personalization. Comput Human Behavior.33. 256-69. doi: 10.1016/j.chb.2014.01.015

Kim, B. H., and Yu, J., 2015. The Importance of Trust for Personalized Online Advertising. Creativity Research Journal, 27(2), 133-138. DOI: 10.1080/10400419.2015.1030302.

Kim, H., and J. Huh., 2017. Perceived Relevance and Privacy Concern Regarding Online Behavioral Advertising (OBA) and Their Role in Consumer Responses. Journal of Current Issues \& Research in Advertising, 38(1), 92-105. https://doi.org/10.1080/10641734.2016.1233157.

Liang, T.P. and Huang, J. S., 1998. An empirical study on consumer acceptance of products in electronic markets: a transaction cost model. Decision Support Systems, 24, 29-43. PII: S0167- 923698 00061-X.

Limpf, N. and Voorveld, H. A. M., 2015. Mobile Location-Based Advertising: How Information Privacy Concerns Influence Consumers' Attitude and Acceptance. Journal of Interactive Advertising, 15(2), 111-123. doi:10.1080/15252019.2015.1064795

Mahatmavidya, P.A. and Yasa, N.N.K., 2020. Advertising Value of Instagram Stories and The Effect on Millennial's Attitude. Russian Journal of Agricultural and Socio-Economic Sciences, 3(99), 29-39. DOI: 10.18551/rjoas.2020-03.04.

Nitzl, C., Roldan, J.L. and Cepeda, G., 2016. Mediation Analysis In Partial Least Squares Path Modeling: Helping Researchers Discuss More Sophisticated Models. Industrial Management \& Data Systems, 116(9), 1849-1864. https://doi.org/10.1108/IMDS-07-2015-0302.

Phelps, J., D'souza, G. and Nowak, G., 2001. Antecedents and consequences of consumer privacy concerns: An empirical investigation. Journal of Interactive Marketing, 15, 2-17. https://doi.org/10.1002/dir.1019.

Piersen, J. and Heyman, B., 2011. Social Media and Cookies: Challenges for Online Privacy. Emerald Group Publishing Limited, 13(6), 30-42. http://dx.doi.org/10.1108/14636691111174243.

Sekaran, U. and Bougie, R., 2016. Research Methods for Business: A SkillBuilding Approach, 7th edition. New York: John Willey and Sons Ltd.

Shim, S., Eastlick, M. A., Lotz, S. L. and Warrington, P., 2001. An online prepurchase intentions model. Journal of Retailing, 77(3), 397-416. DOI:10.1016/s0022-4359(01)00051-3.

Triandis, H. C., 1977. Interpersonal Behavior. Pacific Grove: Brooks/Cole Publishing Company.

Tsang, M. M., Ho, S. C. and Liang, T. P., 2004. Consumer Attitude Toward Mobile Advertising: An Empirical Study. International Journal of Electronic Commerce, 8(3), 65- 78. https://doi.org/10.1080/10864415.2004.11044301. 
Verhagen, T., and van Dolen, W., 2011. The influence of online store beliefs on consumer online impulse buying: A model and empirical application. Information \& Management, 48(8), 320-327. https://doi.org/10.1016/j.im.2011.08.001.

Verplanken, B., and Herabadi, A., 2011. Individual Differences İn İmpulse Buying Tendency: Feeling And No Thinking. European Journal Of Personality, 15, 71-83. https://doi.org/10.1002/per.423. 